\title{
Effects of climate, fire and vegetation development on Holocene changes in total organic carbon concentration in three boreal forest lakes in northern Sweden
}

\author{
P. Rosén ${ }^{1}$ and D. Hammarlund ${ }^{2}$ \\ ${ }^{1}$ Climate Impacts Research Centre, Umeå University, 98107 Abisko, Sweden \\ ${ }^{2}$ GeoBiosphere Science Centre, Quaternary Sciences, Lund University, Sölvegatan. 12, 22362 Lund, Sweden
}

Received: 5 March 2007 - Published in Biogeosciences Discuss.: 26 April 2007

Revised: 10 September 2007 - Accepted: 24 October 2007 - Published: 13 November 2007

\begin{abstract}
Near infrared spectroscopy (NIRS), diatoms, pollen, charcoal, loss-on-ignition (LOI), and nutrient elements in lake sediments were used to assess important factors controlling Holocene changes in the total organic carbon (TOC) concentration, $\mathrm{pCO}_{2}$, color and $\mathrm{pH}$ of lake water in three boreal forest lakes in northern Sweden. The results suggest that mire formation, fire frequency and humidity are the most important forcing factors on millennial timescales. Mires produce humic acids that become available to the lakes, whereas fires may reduce the pool of carbon in the catchments, and humidity controls the transportation of allochthonous carbon into the lakes. Vegetation development and temperature as sole factors are of minor importance for the TOC concentrations in these lakes on a millennial timescale. Two of the sites indicate that liming and possibly fish introduction and rotenone treatment in recent time has led to increased TOC, color and $\mathrm{pH}$ in the lake water, and changed the diatom community composition to an assemblage that has never been present before. Given the predicted climate change scenario that suggests a more humid climate, expanding mires and less frequent fires, our paleolimnological data suggest that TOC concentrations can be expected to increase in boreal forest lakes in the future. Since supersaturation and emission of $\mathrm{CO}_{2}$ from lakes is correlated to the TOC concentration of lake water, higher TOC concentrations may lead to increased emission of $\mathrm{CO}_{2}$ from lakes to the atmosphere.
\end{abstract}

\section{Introduction}

The observed increased concentration of total organic carbon (TOC) in lakes, rivers and coastal areas is of great concern today (Freeman et al., 2001). The reasons for increased

Correspondence to: P. Rosén

(peter.rosen@emg.umu.se) levels of TOC are uncertain. Important factors that have been suggested include changes in precipitation, $\mathrm{pH}$, nutrient load, fire regime, temperature, photodegradation, and land use (Schindler et al., 1997; Freeman et al., 2001; Tranvik and Jansson, 2002; Keller, 2005). Allochthonous TOC is important as a heterotrophic energy source, and it influences light penetration in the water, affects biodiversity and $\mathrm{pH}$, protects aquatic ecosystems from UV radiation, but reduces water quality for drinking (Schindler et al., 1997; Molot et al., 2004). Studies have shown that most lakes in the world are net sources of carbon dioxide $\left(\mathrm{CO}_{2}\right)$ to the atmosphere and the $\mathrm{CO}_{2}$ emission is proportional to the lake-water TOC concentration (Kling et al., 1991; Cole et al., 1994; Hope et al., 1996; Jonsson et al., 2003; Sobek et al., 2003; Algesten et al., 2004). Because of these diverse roles, it is crucial to understand how lacustrine ecosystems can interact with the global climate system in the future, i.e. whether lakes will act as sources or sinks of greenhouse gases in response to environmental change. Although substantial work has been carried out on present carbon cycling in boreal forest lakes, the conclusions from these studies are limited by their shortterm temporal nature (Karlsson et al., 2003).

Lake sediments can be used as historical archives of various biotic (and also abiotic) changes, as they constitute a mixture of proteins, lipids, carbohydrates and other biochemically derived tissues of organisms that resided in the lake or its catchment in the past (Meyers and Ishiwatari, 1993). Near-infrared spectroscopy (NIRS) is a sensitive tool to assess the organic and inorganic composition of natural materials (Norris et al., 1976; Osborne and Fearn, 1988; Korsman et al., 1992; Nilsson et al., 1996; Bokobza, 1998; Korsman et al., 1999; Das et al., 2005). Recent studies have shown that NIRS data from lake sediments are correlated to lakewater TOC concentrations and that reconstructions among lake types show similar patterns (Rosén, 2005, Rosén and Persson, 2006). There is no direct relationship between NIR spectra of sediments and TOC concentration of ambient lake

Published by Copernicus Publications on behalf of the European Geosciences Union. 
Table 1. Location and environmental characteristics of the study lakes. $\mathrm{R}=$ rotenone treatment, $\mathrm{L}=$ limed, $\mathrm{S}=$ superphosphate, FI $=$ fish introduction.

\begin{tabular}{|c|c|c|c|}
\hline Variables & Makkasjön & Sotaure & Lundsjön \\
\hline Latitude ( N) & $66^{\circ} 43^{\prime} \mathrm{N}$ & $66^{\circ} 43^{\prime} \mathrm{N}$ & $66^{\circ} 42^{\prime} \mathrm{N}$ \\
\hline Longitude ( E) & $20^{\circ} 35^{\prime} \mathrm{E}$ & $20^{\circ} 36^{\prime} \mathrm{E}$ & $20^{\circ} 36^{\prime} \mathrm{E}$ \\
\hline Altitude (m a.s.1.) & 415 & 425 & 425 \\
\hline Lake area (ha) & 3 & 2 & 3 \\
\hline Drainage area (ha) & 7 & 4 & 90 \\
\hline Drainage area/lake area & 2.3 & 2 & 30 \\
\hline Catchment vegetation & boreal forest & boreal forest & boreal forest \\
\hline Mire & Small mire & No mire & Small mire \\
\hline Lake treatment & R. L. S. FI. & none & R. L. FI. \\
\hline Bedrock & granite & granite & granite \\
\hline Max. depth (m) & 15 & 9 & 8 \\
\hline $\mathrm{pH}$ (units) & 6.1 & 6.2 & 6.2 \\
\hline TOC $\left(\mathrm{mg} \mathrm{L}^{-1}\right)$ & 3.1 & 4.5 & 3.3 \\
\hline $\mathrm{DOC}\left(\mathrm{mg} \mathrm{L}^{-1}\right)$ & 2.9 & 4.6 & 3.3 \\
\hline Sediment core length $(\mathrm{cm})$ & 124 & 70 & 121 \\
\hline Sampling year & 1995 & 2003 & 2003 \\
\hline
\end{tabular}

water. Instead, the correlation between NIR spectra and TOC concentration is due to the fact that lakes with high and low TOC levels, respectively, exhibit quantitatively and qualitatively different NIR signatures of their sediments which in turn is related to different types of vegetation, algae, input from mires and degradation of organic material in the water column.

Diatoms are another paleolimnological tool, which are known to be sensitive indicators to pH (Renberg et al., 1993; Battarbee et al., 1999). Diatom-based models for reconstruction of TOC and color also exist (Korsman and Birks, 1996; Rosén et al., 2000a), but these models may be confounded by the $\mathrm{pH}$ signal. Therefore there is need to combine a variety of different proxies to assess carbon cycling based on lake sediments.

The aim of this study is to demonstrate the potential of NIRS to reconstruct long-term variations in the lake-water TOC concentration and the partial pressure of carbon dioxide $\left(\mathrm{pCO}_{2}\right)$ of boreal forest lakes during the last 10000 years. For the first time, NIRS inferred TOC values are combined with independent paleoecological and sediment stratigraphic data enabling us to further evaluate NIRS as new method for reconstruction of lake water TOC and to assess important forcing factors on carbon cycling. Specific questions addressed include how mire formation, humidity, fire regime, vegetation development, climate, and liming affect lake-water TOC concentrations on millennial time-scales.

\section{Material and methods}

\subsection{Study sites}

The lakes Makkassjön, Lundsjön and Sotaure (unofficial names, $66^{\circ} 43^{\prime} \mathrm{N}, 20^{\circ} 35^{\prime} \mathrm{E}$ ) are situated within $2 \mathrm{~km}$ from each other in a nutrient-poor, pine heath, kettle-hole area dominated by Scots pine (Pinus sylvestris L.) of EricaceaeCladina type mixed with Norway spruce (Picea abies (L.) Karsten) and some isolated birch (Betula pubescens L.) (Table 1, Fig. 1). Makkassjön and Lundsjön have small mires adjacent to their lake margins. According to a local fishery board, Makkassjön and Lundsjön were treated with rotenone in $1965\left(0.3 \mathrm{mg} \mathrm{l}^{-1}\right)$ and the lakes have supported continuous stocks of introduced arctic char (Salvelinus alpinus L.) since then. Both lakes were limed in 1990 (3000 kg of dolomite lime) and Makkassjön was also treated with superphosphate $\left(\mathrm{Ca}\left(\mathrm{H}_{2} \mathrm{PO}_{4}\right)_{2}\right)$. Prior to liming Makkassjön had a $\mathrm{pH}$ of 5.5, an alkalinity of $3 \mu \mathrm{eq} \mathrm{L}^{-1}$, a color value of $10 \mathrm{mg} \mathrm{PtL}^{-1}$ and a total phosphorus concentration of $4 \mu \mathrm{gl}^{-1}$. In October 1990 the $\mathrm{pH}$ was 6.4, and in March 1992 the $\mathrm{pH}$ was 5.6 and the alkalinity $120 \mu \mathrm{eq} \mathrm{L} \mathrm{L}^{-1}$. The mean annual air temperature (1961-1990) for the nearby village Jokkmokk is $-1^{\circ} \mathrm{C}$, while the mean January temperature is $-16.6^{\circ} \mathrm{C}$, mean July temperature is $14.2^{\circ} \mathrm{C}$, and mean annual precipitation is $497 \mathrm{~mm}$ (Alexandersson et al., 1991).

The sediment record from Lake Makkassjön has previously been subject to reconstruction of lake-water chemistry in relation to Holocene changes in vegetation and fire frequency based on diatom, charcoal and pollen records (Korsman and Segerström, 1998). 
Table 2. Approximate dates from Makkasjön, Lundsjön, Sotaure, using spheroidal carbonaceous particles (SCP) from fossil fuel combustion (Renberg and Wik, 1985), lead pollution history (Renberg et al., 2001), vegetation development (Tallantire, 1977, Segerström, 1990, Huntley and Birks, 1983) and radiocarbon dates. Calibrated ages are based on the IntCal04 radiocarbon calibration curve (Reimer et al., 2004) and are expressed as $2 \sigma$ intervals. The indirect dates are based on studies using radiocarbon dating or annually laminated sediments. $\mathrm{TM}=$ terrestrial macrofossil. $*=$ dates not included in the age-depth model.

\begin{tabular}{lcccc}
\hline Lake & Material & Sediment depth $(\mathrm{cm})$ & Dates $\left({ }^{1} 4 \mathrm{C}\right.$ yrs. BP) & Calibrated age (yrs. BP) \\
\hline Makkasjön & SCP & 2 & - & 35 \\
Makkasjön & $\mathrm{SCP}$ & 7 & - & 55 \\
Makkasjön & ${ }^{206} \mathrm{~Pb} /{ }^{207} \mathrm{~Pb}$ & 30 & - & 1000 \\
Makkasjön & $\mathrm{Picea}$ & 42 & - & 2500 \\
Makkasjön & Alnus & 120 & - & 9000 \\
Lundsjön & SCP & 2 & - & 35 \\
Lundsjön & SCP & 8 & - & 55 \\
Lundsjön & TM & $45^{*}$ & $3525 \pm 90$ & $3555-4105$ \\
Lundsjön & TM & 63 & $3840 \pm 45$ & $4420-4140$ \\
Lundsjön & TM & $86^{*}$ & $7300 \pm 80$ & $8320-7960$ \\
Lundsjön & TM & 91 & $5005 \pm 50$ & $5905-5645$ \\
Lundsjön & TM & 124 & $8085 \pm 60$ & $9265-8765$ \\
Sotaure & TM & 26 & $4100 \pm 40$ & $4835-4445$ \\
Sotaure & TM & 54 & $6300 \pm 50$ & $7425-7025$ \\
Sotuare & TM & 68 & $8510 \pm 60$ & $9565-9415$ \\
\hline
\end{tabular}

\subsection{Field and laboratory methods}

Holocene sediment cores from Makkassjön (1.25 m), Lundsjön $(1.21 \mathrm{~m})$ and Sotaure $(0.70 \mathrm{~m})$ were sampled from the deepest parts of the lakes using a Russian peat corer. Surface sediments were taken using a gravity corer (Renberg, 1991).

Historical TOC concentration of the lake water was inferred from NIRS spectra of the lake sediments using a 100lake calibration set from the area surrounding the study sites (Rosén, 2005). Every centimeter was analyzed for NIRS for the down-core reconstructions. Prior to NIRS analysis sub-samples of about $2 \mathrm{~cm}^{3}$ of wet sediment were freezedried and ground in a mortar. NIR spectra were recorded using a NIRSystems 6500 instrument (FOSS NIRSystems Inc., Silver Spring, MD, USA). The instrument measured diffuse reflectance $(R)$, which was transformed to apparent absorbance values $(A)$ according to $A=\log (1 / R)$. Data were collected at 2-nm intervals between 400 and $2500 \mathrm{~nm}$, yielding 1050 data points per sample. Sample preparation and analyses of pollen, diatoms, charcoal and LOI $\left(550^{\circ} \mathrm{C}\right)$ followed standard methods as described in Korsman and Segerström (1998). Total elemental carbon and nitrogen contents were measured on dried and homogenized sub-samples using a Costech Instruments ECS 4010 elemental analyzer. The accuracy is within $\pm 5 \%$ of the reported values based on replicate analyses of standard material. Total carbon content is used as a proxy for organic matter content of the sediments. Atomic $\mathrm{C} / \mathrm{N}$ ratios are used mainly as a basis for assessment of changing proportions of terrestrial versus aquatic organic matter sources (Meyers and Lallier-Verges, 2001).
Water samples for TOC concentration measurements were taken from $1 \mathrm{~m}$ water depth at the same occasion as the sediment sampling using a Limnos-type water sampler. Water chemistry was analyzed by an accredited laboratory within 2 days after collection (Miljölaboratoriet, Umeå).

\subsection{Dating}

Radiocarbon dating of terrestrial macroscopic plant remains was performed using accelerator mass spectrometry (AMS). Two anomalously old dates obtained at 86 and $45 \mathrm{~cm}$ depth in Lundsjön were interpreted as resulting from re-deposition of catchment soil material, and were excluded from the agedepth model (Table 2). For Makkassjön and Lundsjön approximate dates of recent sediment layers were also inferred from concentrations of spheroidal carbonaceous fly ash particles (SCP, fly ash) (Renberg and Wik, 1985; Wik and Renberg, 1996) (Table 2). The SCP data show that $7 \mathrm{~cm}$ depth in Makkassjön and $8 \mathrm{~cm}$ depth in Lundsjön correspond to the increase in fossil fuel combustion following the Second World War (c. 1950 AD) and the maximum SCP concentration at $2 \mathrm{~cm}^{(c .} 1200 \mathrm{SCP} \mathrm{g}^{-1}$ dry sediment for Makkassjön and $2300 \mathrm{SCP} \mathrm{g}^{-1}$ dry sediment for Lundsjön) corresponds to the peak in oil consumption in the early 1970s. No SCPs were found below $8 \mathrm{~cm}$ depth in any of the lakes. Changes in the ${ }^{206} \mathrm{~Pb} /{ }^{207} \mathrm{~Pb}$ ratio and lead concentration at $30 \mathrm{~cm}$ depth in Makkassjön correspond to a general increase in the atmospheric fall-out of pollution lead in northern $\mathrm{Eu}-$ rope at c. 1000 cal. yrs BP (Renberg et al., 2001). At $42 \mathrm{~cm}$ depth the Picea pollen frequency reaches 5\% in Makkassjön, which is usually regarded as reflecting Picea establishment 


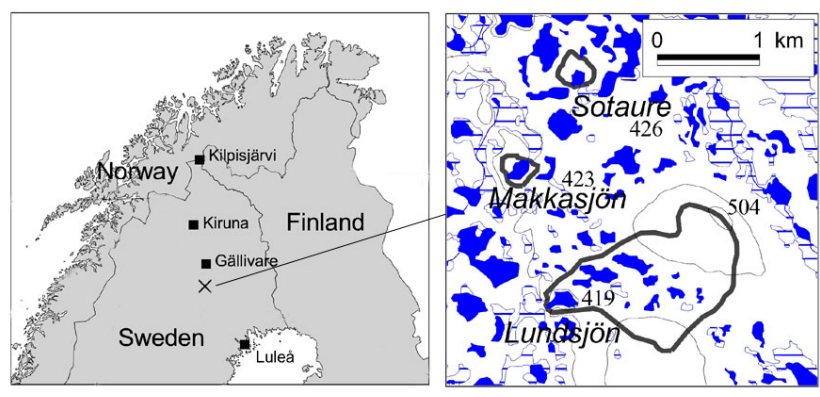

Fig. 1. Map showing the study area and the three study lakes Makkassjön, Lundsjön and Sotaure. The thick lines indicate the drainage areas and blue horizontal line indicate mires.

in the catchment area; the establishment of Picea in northern Scandinavia is dated to $3000-2500 \mathrm{cal}$. BP (Tallantire, 1977; Segerström, 1990). The high abundance of Alnus at $120 \mathrm{~cm}$ depth in Makkassjön corresponds to the regional maximum of Alnus at c. 9000 cal. BP (Tallantire, 1974; Huntley and Birks, 1983). Age-depth models for the sites were based on linear interpolation between the calibrated radiocarbon dates. For the interpretation of the results, it is important to keep in mind that the uncertainties in the chronologies are large inherent to the ${ }^{14} \mathrm{C}$ method and relatively few dates. However, we feel confident with the general comparison of the three lakes since only general trends are compared.

\subsection{Numerical analyses}

Spectral variation arising from varying effective path lengths and particle size was removed using multiplicative signal correction (MSC) prior to all NIRS analyses (Geladi et al., 1985; Martens and Næs, 1989). The aim of the method is to remove variation in spectra caused by between-sample scatter variations in order to linearize the spectra and eliminate variation caused by noise. In this way the remaining variation is only supposed to contain chemical information about the samples.

It can be argued that the NIRS-inferred TOC concentration only reflects the organic content of the sediment (as inferred from loss-on-ignition) because NIRS can be sensitive to the organic content as well as the organic composition of sediment like proteins, lipids, carbohydrates and other biochemicals derived from tissues of organisms formerly living in a lake and its catchment. However, in a previous study correlation coefficients $\left(R^{2}\right)$ in the range of $0.0-0.8$ between NIRSinferred TOC concentration in lake water and LOI $\left(550^{\circ}\right)$ in eight Holocene sediment cores indicates that NIRS can capture a large variation that cannot be accounted for solely by LOI (Rosén 2005). It is well established that the NIRS signal is sensitive to the composition of organic material and not only content (Bokobza, 1998), which is supported by a whole-basin study based on surface sediments (Korsman et al., 1999) and quantitative estimates of pigments (Das et al., 2005). Furthermore, a degradation effect could not be demonstrated when the NIRS signal of sediment from 0 $1 \mathrm{~cm}$ and $1-2 \mathrm{~cm}$ in 56 lakes from the same area was compared using partial least squares discriminant analysis (PLSDA) (Rosén et al., 2000b).

To assess the TOC of lake water, TOC measurements were regressed on NIR spectra of surface sediment samples by partial least square regression (PLS) (Martens and Næs, 1989). PLS regression summarizes the numerous independent wavelengths from the NIR spectra into a few orthogonal components. TOC values were normalized and transformed. The best model was selected as the one that produced the lowest root mean squared error of calibration (RM$\mathrm{SECV}$ ) and $R_{\mathrm{CV}}^{2}$ assessed by internal cross-validation (CV) with ten groups. The SIMCA-P 10.0 (Umetrics AB, SE90119 Umeå, Sweden) software was used for multivariate data analysis for NIRS. The 4-component PLS model between NIRS and TOC has a $R_{\mathrm{CV}}^{2}$ of 0.61 and a RMSEP of $1.6 \mathrm{mg} \mathrm{l}^{-1}$ (11\% of the gradient). For further details about the NIRS model see Rosén (2005). In an attempt to assess past changes in $\mathrm{pCO}_{2}$ the correlation between TOC and $\mathrm{pCO}_{2}$ was assumed to be constant over time and the inferred TOC values were transferred to $\mathrm{pCO}_{2}$ using a relationship assessed from lakes in the same region as the studied lakes (Jonsson et al., 2003):

$\mathrm{pCO}_{2}=295+62[\mathrm{TOC}]$

Weighted averaging (WA) was used to infer color and $\mathrm{pH}$ from the diatom community composition using the program WACALIB version 3.2 (Line and Birks, 1990; Line et al., 1994). The calibration set consists of 115 diatom taxa and 118 north Swedish lakes. The root mean square errors of prediction (jack-knifed) of the calibration models were $35 \mathrm{mg} \mathrm{Pt} \mathrm{L}^{-1}$ for color and 0.4 for $\mathrm{pH}$. For further details about the diatom calibration models, see Korsman and Birks (1996) and Korsman and Segerström (1998).

\section{Results and discussion}

When interpreting the data it is important to consider firstly, that any inferred change between samples is within the prediction error of the models and secondly, that there are large uncertainties in the chronology associated with the ${ }^{14} \mathrm{C}$ dating. Thus, only trends which are supported by independent paleolimnological data or which can be repeated between lakes should be interpreted.

Based on the NIRS-inferred TOC concentrations the sediment records of the three lakes, particularly Makkassjön, are divided into five periods (Fig. 2): the post-glacial period in the early Holocene, 9700-7000 cal. yrs BP; the midHolocene, 7000-4000 cal. yrs BP; 4000-2700 BP; 2700 $1200 \mathrm{BP}$; and the last millennium, $1200 \mathrm{BP}-$ present.

During the early Holocene $(9700-7000$ cal. yrs BP) the NIRS records from Lundsjön and Sotaure infer low TOC val- 


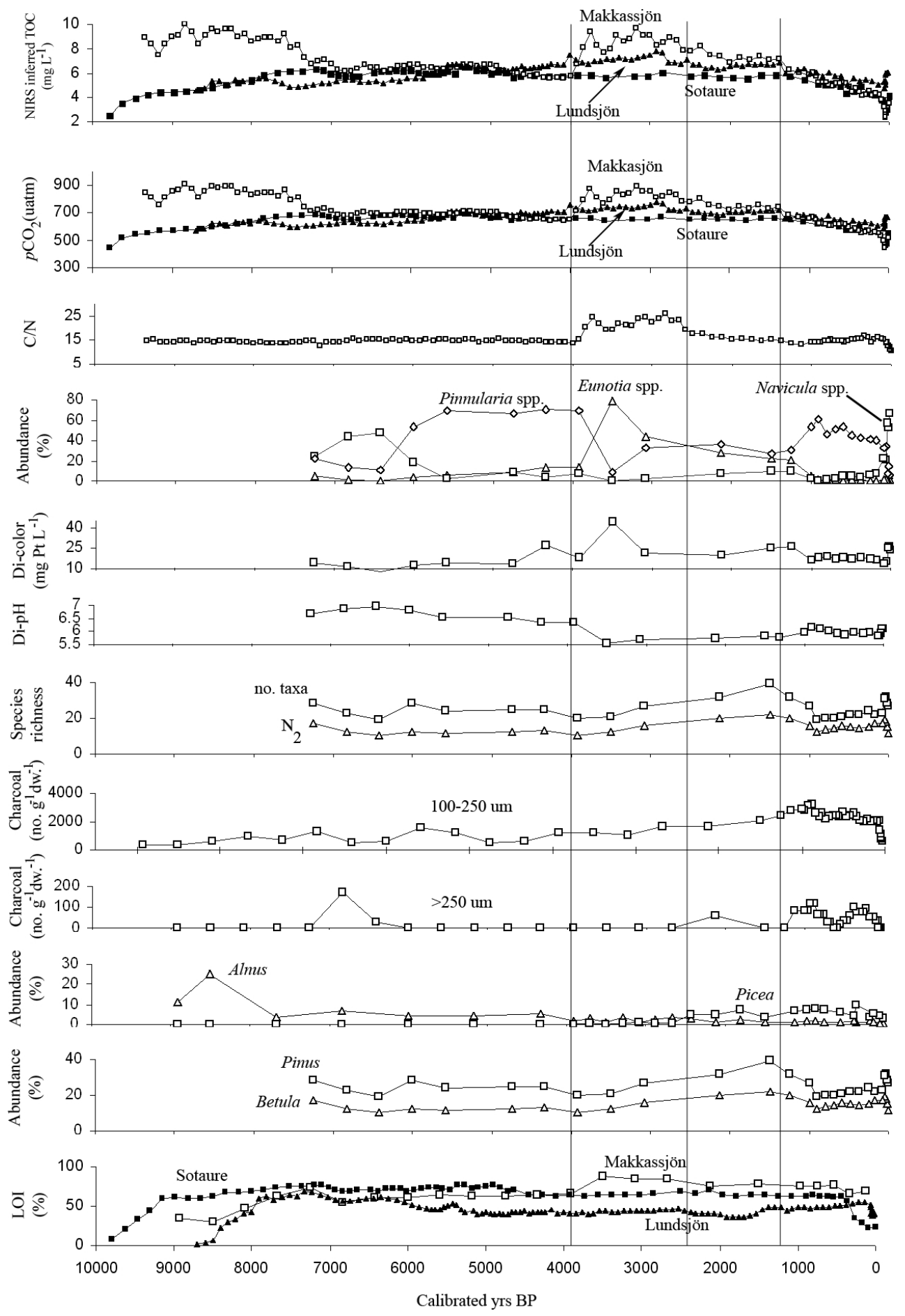

Fig. 2. Records of NIRS-inferred total organic carbon (TOC) concentration and $\mathrm{pCO}_{2}$ of lake water and sediment organic matter content based on loss-on-ignition (LOI) obtained from Holocene sediment cores from Lakes Makkassjön, Lundsjön, and Sotaure. From Lake Makkassjön results from atomic $\mathrm{C} / \mathrm{N}$ ratio, diatom analysis, diatom inferred color (Di-color), diatom inferred $\mathrm{pH}$ (Di-pH), diatom species richness expressed as number of taxa and sample heterogeneity (Hill's $\mathrm{N}_{2}$ ), charcoal from fires, percentage values of pollen are also shown. All data with open marks refer to Lake Makkassjön. $\mathrm{pCO}_{2}$ values were derived from NIRS inferred TOC using the equation: $\mathrm{pCO}_{2}=295+62[\mathrm{TOC}]$. 
ues, with a gradual increase from 2 to about $4 \mathrm{mg} \mathrm{TOC} \mathrm{L}^{-1}$. These low values are probably a result of limited carbon pools in their catchments during early soil and vegetation development after deglaciation. This is supported by low LOI values, which indicate unstable soils and abundant catchment erosion, and also a dominance of pioneer plant taxa like Salix, Alnus, Betula, and various herbs at this stage (Korsman and Segerström, 1998).

At nearby Makkassjön, however, NIRS infers high TOC values in spite of a presumably similar vegetation development. Often, interpretations of sediment records from early Holocene can be difficult due to soil forming processes, vegetation development and lack of modern analogues in the calibration set (e.g. Rosén et al., 2003; Bigler et al., 2003) and the TOC reconstructions from the early Holocene should therefore be interpreted with caution. Possible explanations for the higher inferred TOC in Makkassjön, 6$8 \mathrm{mg} \mathrm{TOC} \mathrm{L}{ }^{-1}$, include absence of local fires (Korsman and Segerström, 1998), higher $\mathrm{pH}$ and also probably a generally more humid climate (Hammarlund et al., 2002; Korhola et al., 2005). Humid climatic conditions favor transportation of allochthonous carbon into lakes and higher $\mathrm{pH}$ can decrease photooxidation of DOC (Gennings et al., 2001).

From c. 7000 to 4000 cal. yrs BP all three lakes show an almost constant inferred TOC concentration, about 5$6 \mathrm{mg} \mathrm{TOCL}^{-1}$. The diatom flora and species richness recorded at Makkassjön also show only minor changes (Fig. 2). During this time there were no major changes in vegetation, and low concentrations of large charcoal fragments indicate a low fire frequency in the area (Korsman and Segerström, 1998). A largely constant organic matter content for all three lakes at persistently high levels indicate more stable soil conditions than in the period prior to 7000 cal. yrs BP. Although this period generally corresponds to the Holocene thermal maximum in northern Fennoscandia it is clear that a slightly warmer climate $\left(1-2^{\circ} \mathrm{C}\right)$ prevailed around 7000 as compared to 4000 cal. yrs BP (Hammarlund et al., 2002; Rosén et al., 2003; Bigler et al., 2003). The results therefore indicate that temperature by itself is not an important factor for the long-term TOC variation in the studied lakes.

Around 4000 cal. yrs BP the NIRS-inferred TOC concentration increases from c. 6 to $9 \mathrm{mg} \mathrm{L}^{-1}$ at Makkassjön and it remains high until c. 2700 cal. yrs BP (Fig. 2). This increase is accompanied by a distinct change in the diatom community composition towards dominance of acidophilous species like Eunotia spp. and the diatom-inferred $\mathrm{pH}$ decreases from 6.4-6.6 to 5.5-5.8 and the diatom-inferred color increases and has the highest value during the entire Holocene. Although the maximum value of diatom inferred color corresponds with a period of high TOC values, no clear relationship was observed between these two variables despite previous findings that color can be used as an estimate for TOC concentrations of lake water (Rasmussen et al., 1989) and statistical significant models have been used for both color
(Korsman and Birks, 1996) and TOC (Rosén, 2005).

The first pollen grains of Picea appear at this time, although Picea did not become established in the area until $1000-1500$ yrs later. It is argued that Picea expanded in Scandinavia around 4000 cal. yrs BP, when there was a shift towards a more humid climate. Local establishment of Picea in northern Sweden took place around 3000-2500 cal. yrs BP (Tallantire, 1977; Segerström, 1990; Giesecke and Bennett, 2004). A generally humid climate is supported by low frequencies of charcoal in the sediments.

Humid conditions generally favor mire expansion and lead to increased production of humic substances (i.e. organic acidity) and thus also to an increased mobility and flux of allochthonous organic carbon to lakes. Such a development is consistent with an increase from 12 to 20 in the $\mathrm{C} / \mathrm{N}$ ratio of sediment organic matter at Makkassjön during the period c. $4000-2700 \mathrm{cal}$. yrs BP, which probably reflects an elevated input of terrestrial organic detritus to the lake. Also at Lundsjön, which is connected to a small mire, the NIRS-inferred TOC record exhibits maximum Holocene values during the period c. 4000-2700 cal. yrs BP. Corresponding data from Sotaure show no changes at this stage, which probably reflects the absence of mires in the catchment of this lake. The results agree well with several other studies showing the importance of wetlands for the export of TOC to lakes and streams (Kortelainen, 1993; Dillon and Molot, 1997; Creed et al., 2003; Laudon et al., 2004).

Between 2700 and 1200 cal. yrs BP the two lakes with adjacent mires (Makkassjön and Lundsjön) begin to show a gradual decrease in NIRS-inferred TOC concentration (Fig. 2). At the same time $\mathrm{pH}$ and diatom species richness (number of taxa and sample heterogeneity, Hill's $\mathrm{N}_{2}$ ) increase slightly. Numerous paleolimnological studies of boreal forest lakes show a gradual decrease in lake-water $\mathrm{pH}$ during the Holocene due to natural acidification in boreal forest lakes in the absence of human impact (Renberg et al., 1993; Engstrom et al., 2000; Boyle, 2007). Human impact may, however, have a neutralizing effect on lakes due to activities in the catchment (Renberg et al., 1993), but early settlements between $3500-1000$ yrs BP are unlikely to have occurred around Makkassjön. Instead, increased fire frequency and possibly a generally drier climate, indicated by an increasing abundance of both small and large charcoal fragments, can be the reason for these changes in the diatoms (Korhola et al., 1996). Drier conditions can also have reduced mire expansion and the input of allochthonous carbon and humic acids to the lakes, and such a development would explain the lower inferred TOC values and the slight increase in $\mathrm{pH}$. Evidence of relatively frequent lightninginduced wildfires during the last 2000-3000 years has also been obtained from studies of mor humus and sediment profiles in the boreal forests of northern Sweden and Finland (Bradshaw and Zackrisson, 1990; Virkanen, 2000), which suggests a more continental climate during this period. Several other studies have shown that a drier climate can have 
a strong effect on the export of allochtonous carbon to lakes (e.g. Schindler et al., 1997).

All three lakes show a decreasing trend in NIRS-inferred TOC concentration from c. 1200 cal. BP to 1965 AD (Fig. 2). Concomitantly diatom species richness in Makkassjön decreases with Eunotia spp. almost absent and Pinnularia spp. becoming more abundant following a long-term decrease. The diatom-inferred $\mathrm{pH}$ remains at slightly higher values around 6 . The reason for lowered TOC concentrations is probably a combination of drier climate and more abundant local fires as indicated by relatively high frequencies of large charcoal fragments (>250 um). The TOC concentrations decline to levels lower than prior to the mire expansion at c. 4000 cal. yrs BP. It is likely that all three lakes have experienced similar fire regimes, because they are situated only $2 \mathrm{~km}$ apart and have similar catchment vegetation. Fires can both have a positive and negative effect on the TOC export to lake. Extensive fires where soil pools are eliminated due to intense or repeated burns may decrease the export of TOC to lakes (Schindler et al., 1997). In contrast, lesser extensive burns might increase the TOC flux if erosion of fine particulate organic matter increases. Schindler et al. (1997) could not see an obvious step in the general declining trend in DOC inputs following two extensive forest fires suggesting that that drought is the factor primarily responsible for the observed decline in DOC. In our study we cannot separate the possible effects of drier climate and fires but our results suggest that climate has an important influence on TOC levels in boreal lakes, either through hydrological effects or possibly indirectly through the frequency of wildfires.

Around 1965 the NIRS-inferred TOC concentration shows a small (c. $1 \mathrm{mg} \mathrm{L}^{-1}$ ) but sudden increase in Makkassjön and Lundsjön (Fig. 3). Also the diatom-inferred color and $\mathrm{pH}$ increase, and there is a marked change in the diatom community to a composition without any past analogue. The diatom community is characterized by very high frequencies of Navicula seminulum var. intermedia (c. 60\%). The number of taxa also increased but the sample heterogeneity remained low (Fig. 2). Shortly before the recent artificial limnological changes the records of sediment organic matter content at Makkassjön and Lundsjön exhibit well-defined transient decreases which are centered at the beginning of 20th century (Fig. 3). These patterns, which are accompanied by distinct minima in the NIRS-inferred TOC records, are probably related to an input of detrital minerogenic matter during the construction of roads near the lakes. The marked decline in the $\mathrm{C} / \mathrm{N}$ ratio at Makkassjön throughout the last century may to some extent reflect the combined effects of road construction, liming, fertilization and fish introduction. This repeatedly supplied the aquatic ecosystem with nutrients and thereby led to increased proportions of aquatic versus terrestrial organic matter in the sediments. The liming treatments of Makkassjön and Lundsjön in 1965, followed by rotenone treatment and introduction of arctic char, have likely contributed to the increased TOC concentration in the lake wa-
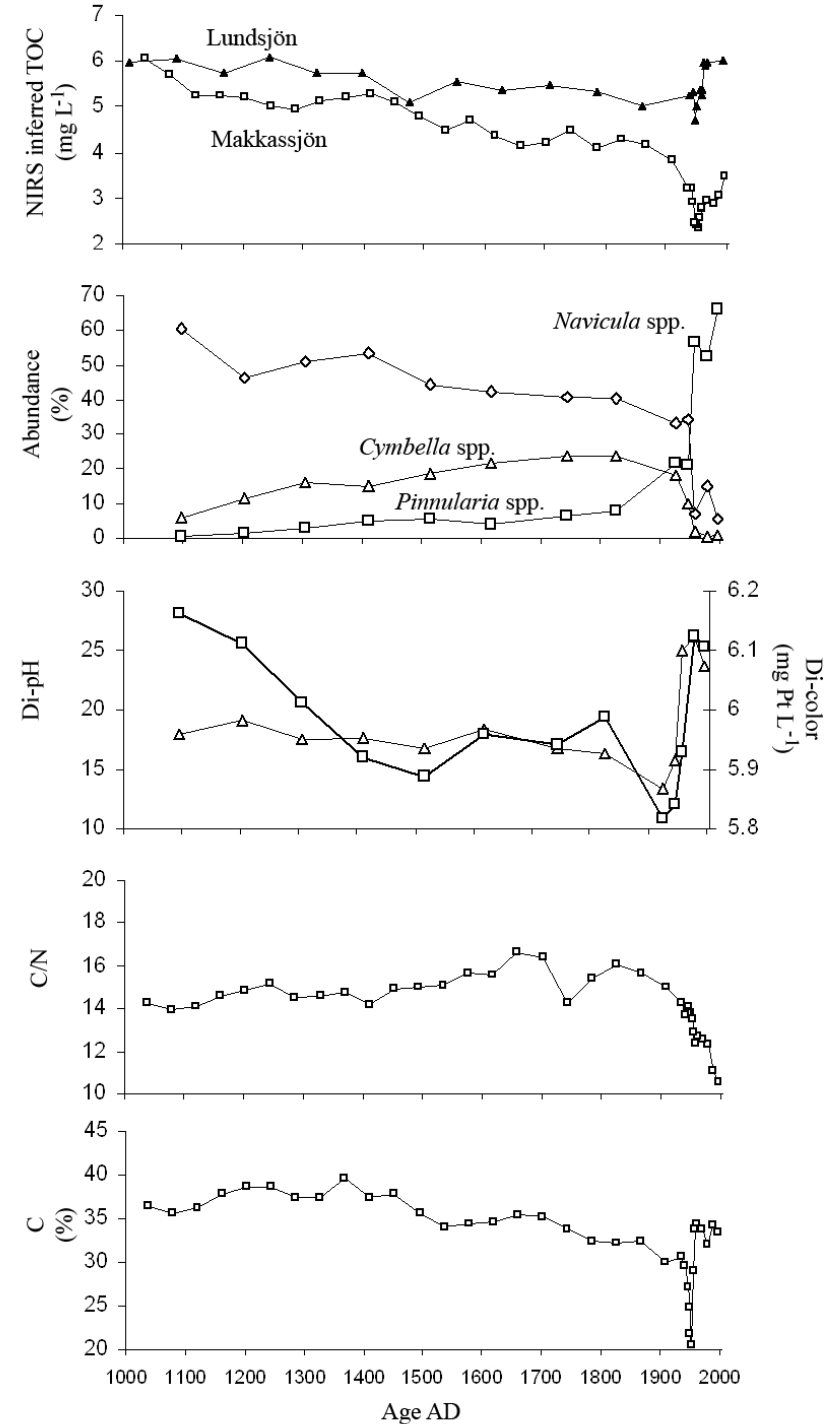

Fig. 3. NIRS-inferred total organic carbon (TOC) concentration in lake water during the last 1000 yrs from Lake Makkassjön and Lundsjön. From Lake Makkassjön results from diatom analysis, diatom inferred colour (Di-color), diatom inferred $\mathrm{pH}$ (Di-pH), atomic $\mathrm{C} / \mathrm{N}$ ratio and carbon $\%$ are also shown. All data with open marks refer to Lake Makkassjön. Since AD 1965 Makkasjön and Lundsjön were treated with liming, fertilization, rotenone and introduction of char.

ters. Liming has been reported to have both a positive and negative effect on TOC (Hindar et al., 1996; Andersson et al., 1997). Liming can decolorize organic matter and increase the transparency of lake water. However, generally photooxidation is less important in lakes with high $\mathrm{pH}$ and liming can therefore decrease the mineralization of organic carbon. Liming in the catchment can also increase nitrogen $(\mathrm{N})$ mobilization and leakage of $\mathrm{N}$ and DOC to lakes (Hindar et al., 1996; Andersson et al., 2000). The Sotuare record shows no change in inferred TOC concentration during recent decades, and this lake has not been manipulated. 


\section{Conclusions}

This study indicates that NIRS can be used for reconstructions of lake water TOC and demonstrates several important links between terrestrial and limnic ecosystems. Assuming that the correlation between TOC and $\mathrm{pCO}_{2}$ has been constant over time the results indicate that all three lakes have been supersaturated with $\mathrm{CO}_{2}$ during the entire Holocene and have therefore been a source of carbon to the atmosphere. On millennial timescales, humidity, mire formation and fires are among the most important factors controlling the TOC concentration of boreal forest lakes. The single most important process at our study site was the expansion of a mire to the margin of Lake Makkassjön around 4000 cal. yrs BP, which resulted in a sudden increase in the lake-water TOC concentration. Drier and possibly more continental climatic conditions reduced the TOC concentration in two mire-influenced lakes between 2700 and $1200 \mathrm{cal}$. yrs BP. An increase in fire frequency under relatively dry climatic conditions after 1200 cal. yrs BP led to reduced TOC concentrations in all three lakes. Liming, rotenone treatment and introduction of char increased the TOC concentration and $\mathrm{pH}$ during the last 40 yrs. Long-term forest dynamics have probably only had minor direct effects on the TOC concentrations, even though the vegetation has shifted from a dominance of Alnus and Betula in the early Holocene to Pinus-dominated forest during the mid Holocene and a mixed forest with Pinus and Spruce during the last 2700 years.

The results suggest that temperature as a sole factor is not an important factor for long-term TOC concentration in boreal forest lakes. None of the lakes showed any changes in TOC concentration between 7000 and $4000 \mathrm{cal}$. yrs BP when temperature reportedly changed by $1-2^{\circ} \mathrm{C}$. Elevated lakewater $\mathrm{pH}$ correlated well with low lake-water TOC concentrations, frequent fires and relatively dry climatic conditions. This could be explained by dry climatic conditions and frequent fires which reduce the amount of humic acids in the catchments and the transportation of allocthonous carbon to boreal lakes. High diatom species richness corresponds well with lowered TOC levels under relatively dry climatic conditions but species richness decreased during periods with frequent fires and elevated lake-water $\mathrm{pH}$. Given the predicted future scenario with a more humid climate, mire expansion and less abundant fires, our results suggest that TOC concentrations in boreal forest lakes may increase, which in turn may result in larger emissions of $\mathrm{CO}_{2}$ to the atmosphere.
Acknowledgements. This research was supported by the EC Environment and Climate Research Programme (contract ENV4CT97-0642, Climate and Natural Hazards), the Climate Impacts Research Centre (CIRC) via funding from EU Structural Funds and Swedish Regional Funds to the Environment and Space Research Institute in Kiruna and the Crafoord foundation. We thank T. Korsman and U. Segerström for providing lake sediments and previous published data from Lake Makkassjön, T. Westin for field assistance, R. Bindler and C. Säwström for valuable comments on the manuscript.

Edited by: Y. Prairie

\section{References}

Aas, B. and Faarlund T.: The Holocenen history of the Nordic mountain birch belt, p 5-22. In F.E. Wielgolaski (ed.). Nordic mountain birch ecosystems, Man and the biosphere series vol. 27, The Parthenon Publishing Group, London, UK, 2001.

Alexandersson, H., Karlström, C., and Larsson-McCann, S.: Temperaturen och nederbörden i Sverige 1961-1990, SMHI, the Swedish Meteorological and Hydrological Institute, 81, 1-88, 1991.

Algesten, G., Sobek, S., Bergstrom, A. K., Ågren, A., Tranvik, L. J., and Jansson, M.: Role of lakes for organic carbon cycling in the boreal zone, Global Change Biol., 10, 141-147, 2004.

Anderson, N. J., Blomquist, P., and Renberg, I.: An experimental and palaeoecological study of algal responses to lake acidifcation and liming in three central Swedish lakes, Eur. J. Phyc., 32, 3548, 1997.

Andersson, S., Nilsson, S. I., and Saetre, P.: Leaching of dissolved organic carbon (DOC) and dissolved organic nitrogen (DON) in mor humus as affected by temperature and $\mathrm{pH}$, Soil Biol. \& Biochem., 32, 1-10, 2000.

Barnekow, L.: Holocene tree-line dynamics and inferred climatic changes in the Abisko area, northern Sweden, based on macrofossil and pollen records, The Holocene, 9, 253-265, 1999.

Battarbee, R. W., Charles, D. F., Dixit, S. S., and Renberg, I.: Diatoms as indicators of surface waters, in: The diatoms: Applications for the environment and earth science, edited by: Stroemer, E. F. and Smol, J. P., Cambridge University Press, 85-127, 1999.

Bigler, C., Grahn, E., Larocque, I., Jeziorski, A., and Hall, R. Holocene environmental change at Lake Njulla (999 m a.s.1.), northern Sweden: a comparison with four nearby lakes along an altitudinal gradient, J. Paleolim., 29, 13-29, 2003.

Birks, H. J. B.: Numerical tools in palaeolimnology - Progress, potentialities, and problems, D. G. Frey and E. S. Deevey Review \#1, J. Paleolim., 20, 307-332, 1998.

Boyle, J. F: Loss of apatite caused irreversible early Holocene lake acidification, The Holocene, 17(4), 543-547, 2007.

Bokobza, L.: Near infrared spectroscopy, J. Near Infrared Spec., 6, 3-17, 1998.

Bradshaw, R. H. W. and Zackrisson, O.: A two thousand year history of northern Swedish boreal forest stand, J. Veg. Sci., 1, 519$528,1990$.

Cole, J. J., Caraco, N. F., Kling, G. W., and Kratz, T. K.: Carbon dioxide supersaturation in the surface waters of lakes, Science, 265, 1568-1570, 1994. 
Creed, I. F., Sanford, S. E., Beall, F. D., Molot, L. A., and Dillon, P. J.: Cryptic wetlands: integrating hidden wetlands in regression models of the export of dissolved organic carbon from forested landscapes, Hydrol. Proc., 17, 3629-3648.

Das, B., Vinebrooke, R. D., Sanchez-Azofeifa, A., Rivard, B., and Wolfe, A. P.: Inferring sedimentary chlorophyll concentrations with reflectance spectroscopy: a novel approach to reconstructing historical changes in the trophic status of mountain lakes, Can. J. Fish Aquat. Sci., 62, 1067-1078, 2005.

Dillon, P. J. and Molot, L. A.: Effects of landscape form on export of dissolved organic carbon, iron, and phosphorus from forested stream catchments, Water Resour. Res., 33, 2591-2600, 1997.

Engstrom, D. R., Fritz, S. C., Almendinger, J. E., and Juggins, S.: Chemical and biological trends during lake evolution in recently deglaciated terrain, Nature, 408, 161-166, 2000.

Freeman, C., Evans, C. D., and Monteith, D. T.: Export of organic carbon from peat soils, Nature, 412, p. 785, 2001.

Geladi, P., MacDougall, D., and Martens, H.: Linearization and Scatter-Correction for Near-Infrared Reflectance Spectra of Meat, Appl. Spectrosc., 39, 491-500, 1985.

Gennings, C., Molot, L. A., and Dillon, P. J.: Enhanced photochemical loss of organic carbon in acidic waters, Biogeochemistry, 52, 339-354, 2001.

Hammarlund, D., Barnekow, L., Birks, H. J. B., Buchardt, B., and Edwards, T. W. D.: Holocene changes in atmospheric circulation recorded in the oxygen-isotope stratigraphy of lacustrine carbonates from northern Sweden, The Holocene, 12, 339-351, 2002.

Hindar, A., Kroglund, F., Lydersen, E., Skiple, A., and Høgberget, R.: Liming of wetlands in the acidified Lake Røynelandsvatn catchment in southern Norway: effects on stream water chemistry, Can. J. Fish. Aquat. Sci., 53, 985-993, 1996.

Hope, D., Kratz, T. K., and Riera, J. L.: Relationship between $\mathrm{PCO}_{2}$ and dissolved organic carbon in Northern Wisconsin Lakes, J. Environ. Qual., 25, 1442-1445, 1996.

Huntley, B. and Birks, H. J. B.: An atlas of past and present pollen maps for Europe: 0-13000 years ago, Cambridge University Press, Cambridge, 1983.

Jonsson, A., Karlsson, J., and Jansson, M.: Sources of carbon dioxide supersaturation in clearwater and humic lakes in northern Sweden, Ecosystems, 6, 224-235, 2003.

Karlsson, J., Jonsson, A., Meili, M., and Jansson, M.: Control of zooplankton dependence on allochthonous organic carbon in humic and clear-water lakes in northern Sweden, Limnol. Oceanogr., 48, 269-276, 2003.

Keller, W. B., Heneberry, J., and Leduc, J.: Linkages between weather, dissolved organic carbon, and cold-water habitat in a Boreal Shield lake recovering from acidification, Can. J. Fish. Aquat. Sci., 62, 341-347, 2005.

Kling, G. W., Kipphut, G. W., and Miller, M. C.: Arctic lakes and streams as gas conduits to the atmosphere: implications for tundra carbon budgets, Science, 251, 298-301, 1991.

Korhola, A., Virkanen, J., Tikkanen, M., and Blom, T.: Fire-induced $\mathrm{pH}$ rise in a naturally acid hill-top lake, southern Finland: a paleoecological survey, J. Ecol., 84, 257-265, 1996.

Korhola, A., Tikkanen, M., and Weckström, J.: Quantification of Holocene lake-level changes in Finnish Lapland using a cladocera - lake depth transfer model, J. Paleolimnol., 34, 175-190, 2005.

Korsman, T., Nilsson, M. B., öhman, J., and Renberg, I.: Near- infrared reflectance spectroscopy of sediments: a potential method to infer the past pH of lakes, Environ. Sci. Technol., 26, 2122-2126, 1992.

Korsman, T., Renberg, I., and Anderson, N. J.: A paleolimnological test of the influence of Norway spruce (Picea abies) immigration on lake-water acidity, The Holocene, 4, 132-140, 1994.

Korsman, T. and Birks, H. J. B.: Diatom-based water chemistry recontructed from northern Sweden: a comparisson of recontruction techniques, J. Paleolim., 15, 65-77, 1996.

Korsman, T. and Segerström, U.: Forest fire and lake-water acidity in a northern Swedish boreal area: Holocene changes in lakewater quality at Makkassjön, J. Ecol., 86, 113-124, 1998.

Korsman, T., Nilsson, M. B., Landgren, K., and Renberg, I.: Spatial variability in surface sediment composition characterised by near-infrared (NIR) reflectance spectroscopy, J. Paleolim., 21, 61-71, 1999.

Kortelainen, P.: Content of total organic-carbon in Finnish lakes and its relationship to catchment characteristics, Can. J. Fish and Aquat. Sci., 50, 1477-1483, 1993.

Laudon, H., Köhler, S., and Buffam, I.: Seasonal TOC export from seven boreal catchments in northern Sweden, Aquat. Sci., 66, 223-230, 2004.

Leavitt, P. R., Schindler, D. E., Paul, A. J., Hardie, A. K., and Schindler, D. W.: Fossil pigment records of phytoplankton in troutstocked alpine lakes, Can. J. Fish Aquat. Sci., 51, 2411-23, 1994.

Line, J. M. and Birks, H. J. B.: WACALIB version 2.1 a computer program to reconstruct environmental variables from fossil assemblages by weighted averaging, J. Paleolim., 3, 170-173, 1990.

Line, J. M., TerBraak, C. J. F., and Birks, H. J. B.: WACALIB version 3.3 - a computer program to reconstruct environmental variables from fossil assemblages by weighted averaging and to derive sample-specific errors of prediction, J. Paleolim., 10, 147$152,1994$.

Martens, H. and Næs, T.: Multivariate calibration, John Wiley \& Sons, New York, 1989.

Meyers, P. A. and Ishiwatari, R.: Lacustrine organic geochemistry - an overview of indicators of organic-matter sources and diagenesis in lake-sediments, Org. Geochem., 20, 867-900, 1993.

Meyers, P. A. and Lallier-Verges, E.: Lacustrine sedimentary organic matter records of Late Quaternary paleoclimates, J. Paleolimnol., 21, 345-372, 1999.

Molot, L. A. and Dillon, P. J.: Colour - mass balances and colour - dissolved organic carbon relationships in lakes and streams in central Ontario, Can. J. Fish. Aquat. Sci., 54, 2789-2795, 1997.

Molot, L. A., Keller, W., Leavitt, P. R., Robarts, R. D., Waiser, M. J., Art, M. T., Clair, T. A. Pienitz, R., Yan, D. K., McNicol, D. K., Prairie, Y. T., Dillon, P. J., Macrae, M., Bello, R., Nordin, R. N., Curtis, P. J., Smol, J. P., and Douglas, M. S. V.: Risk analysis of dissolved organic matter-mediated ultraviolet B exposure in Canadian inland waters, Can. J. Fish. Aquat. Sci., 61, 25112521, 2004.

Nilsson, M. B., Dåbakk, E., Korsman, T., and Renberg, I.: Quantifying relationships between near-infrared reflectance spectra of lake sediment and water chemistry, Environ. Sci. Technol., 30, 2586-2590, 1996.

Norris, K. H., Barnes, R. F., Moore, J. E., and Shenk, J. S.: Predicting forage quality by near-infrared reflectance spectroscopy, 
J. Anim. Sci., 43, 889-897, 1976.

Osborne, G. B. and Fearn, T.: Near Infrared Spectroscopy in Food Analysis, John Wiley \& Sons, New York, 1998.

Rasmussen, J. B., Godbout, L., and Schallenberg, M.: The humic content of lake water and its relationship to watershed and lake morphometry, Limnol. Oceanogr., 34, 1336-1343, 1989.

Reimer, P. J. and 28 others: IntCal04 terrestrial radiocarbon age calibration, 0-26 Cal K yr BP, Radiocarbon, 46, 1029-1058, 2005.

Renberg, I. and Wik, M.: Soot particle counting in recent lake sediments: an indirect dating method, Ecolog. Bull., 37, 53-57, 1985.

Renberg, I.: The HON-Kajak sediment corer, J. Paleolim., 6, 167170, 1991.

Renberg, I., Korsman, T., and Birks, H. J. B.: Prehistoric increase in the $\mathrm{pH}$ of acid-sensitive Swedish lakes caused by land-use changes, Nature, 362, 824-826, 1993.

Renberg, I., Bindler, R., and Brännvall, M. L.: Using the historical atmospheric lead-deposition record as a chronological marker in sediment deposits in Europe, The Holocene, 11, 511-516, 2001.

Rosén, P., Hall, R., Korsman, T., and Renberg, I.: Diatom transferfunctions for quantifying past air temperature, $\mathrm{pH}$ and total organic carbon concentration from lakes in northern Sweden, J. Paleolim., 24, 109-123, 2000a.

Rosén, P., Dåbakk, E., Renberg, I., Nilsson M., and Hall, R. I.: Near-infrared spectrometry (NIRS): a new tool for inferring past climatic changes from lake sediments, The Holocene, 10, 161166, 2000b.

Rosén, P., Segerström, U., Renberg, I., and Eriksson, L.: Do diatom, chironomid and pollen records consistently infer Holocene July air temperature? A comparison using sediment cores from four alpine lakes in northern Sweden, Arct. Antarct. Alp. Res., 35, 279-290, 2003.
Rosén, P.: Total organic carbon (TOC) of lake water during the Holocene inferred from lake sediments and near-infrared spectroscopy (NIRS) in eight lakes from northern Sweden, Biogeochemistry, 76, 503-516, 2005.

Rosén, P. and Persson, P.: Fourier-transform infrared spectroscopy (FTIRS), a new method to infer past changes in tree-line position and TOC using lake sediment, J. Paleolim., 35, 913-923, 2006.

Schindler, D. W., Curtis, P. J., Bayley, S. E., Parker, B. R., Beaty, K. G., and Stainton, M. P.: Climate-induced changes in the dissolved organic carbon budgets of boreal lakes, Biogeochemistry, 36, 9-28, 1997.

Segerström, U.:The post-glacial history of vegetation and agriculture in the Lulelv river valley, Arch. Environ., 7, 1-79, 1990.

Sobek, S., Algesten, G., Bergström, A. K., Jansson, M., and Tranvik, L. J.: The catchment and climate regulation of $\mathrm{pCO}_{2}$ in boreal lakes, Global Change Biol., 9, 630-641, 2003.

Tallantire, P. A.: The palaeohistory of the grey alder (Alnus incana (L.) Moench.) and black alder (Alnus glutinosa (L.) Gaertn.) in Fennoscandia, New Phytologist, 73, 529-546, 1974.

Tallantire, P. A.: A further contribution to the problem of the spread of spruce (Picea abies (L.) Karst.) in Fennoscandia, J. Biogeogr., 4, 219-227, 1977.

Tranvik, L. J. and Jansson, M.: Climate change - terrestrial export of organic carbon, Nature, 415, 861-862, 2002.

Virkanen, J.: The effects of natural environmental changes on sedimentation in Lake Kuttanen, a small closed lake in Finnish Lapland, The Holocene, 10, 377-386, 2000.

Wik, M. and Renberg, I.: Environmental records of carbonaceous particles from fossil-fuel combustion: a summary, J. Paleolim., 15, 193-206, 1996. 